\title{
Comparative Analysis of the Effectiveness of Reverse Osmosis and Ultraviolet Radiation of Water Treatment
}

\author{
Gabriel B. Dirisu', Ugochukwu C. Okonkwo', Imhade P. Okokpujie ${ }^{2 *}$, Ojo S.I. Fayomii ${ }^{2,3}$
}

1 Department of Mechanical Engineering, Nnamdi Azikiwe University, Awka, Nigeria

2 Department of Mechanical Engineering, College of Engineering, Covenant University Ota, Lagos state, Nigeria

3 Department of Chemical, Metallurgical and Materials Engineering, Faculty of Engineering and the Built Environment, Tshwane University of Technology, Pretoria, South Africa

* Corresponding author's e-mail: imhade.okokpujie@covenantuniversity.edu.ng

\begin{abstract}
Water contamination and pollution pose health hazards to humanity and hence the need for their treatment. This study compared reverse osmosis (RO) and ultra-violet (UV) radiation in treating borehole water (BHW) and surface water (SW). The study area is Omoku community in Rivers State of Nigeria. The RO- and UV-treated waters were determined by their physicochemical characteristics and total Coliform, with the control to check the impact of each one. The obtained results showed slight variations, which were either significant or not. The $\mathrm{pH}$ of the treated BHW was slightly acidic with the value of 6.52 . Water conductivity ranged from $40.33 \mu \mathrm{s} / \mathrm{cm}^{3}$ to $42.40 \mu \mathrm{s} / \mathrm{cm}^{3}$ for the BHW treated with RO, UV and control samples, respectively. SW conductivity attained a range of $425.07-800.0 \mu \mathrm{s} / \mathrm{cm}^{3}$. Turbidity of BHW were beyond the detectable limit but was higher than the WHO limit of $<5.00 \mathrm{NTU}$, while total suspended solid (TSS) of SW ranged from 9.08-46.43 ppm. Total dissolved solids (TDS) values of water were between $3.50 \mathrm{ppm}$ and $16.67 \mathrm{ppm}$ for RO treated BHW and higher than that of SW. There was a reduction of salinity of BHW from $40.7 \mathrm{mg} / \mathrm{l}$ to 11.8 and $21.6 \mathrm{mg} / \mathrm{l}$ following RO and UV treatment, while SW salinity was also reduced from $75.0 \mathrm{mg} / 1$ to $20 \mathrm{mg} / \mathrm{l}$ in RO treated water and $16 \mathrm{mg} / \mathrm{l} \mathrm{in} \mathrm{UV}$ treated water. In this study, RO and UV water treatment proved to be effective in producing potable water from both BHW and $\mathrm{SW}$, although RO seemed to produce water with reduced mineral content in comparison to the UV treatment. Both methods effectively reduced heavy metals as well as Coliform. The physicochemical parameters tested were below the WHO recommended limits in most cases. It is recommended that both methods be incorporated in a single WT in order to gain the benefits of both technologies.
\end{abstract}

Keywords: water treatment, water treatment techniques, ultraviolet radiation, reverse osmosis

\section{INTRODUCTION}

Water is a very significant abiotic parameter, it is often said that "water is life" Adah et al, (2013). Water is an important constituent of the biotic community. In nature, it occurs on surface, underground, in the atmosphere and in the biomass. Globally, $97.54 \%$ of the total volume of water available is in the oceans, $1.81 \%$ stored in the form of ice-sheets, $0.63 \%$ - ground water, $0.007 \%$ - salt water, $0.009 \%$ - fresh water and $0.001 \%$ in the atmosphere (Ademoroti, 1996). Water availability and quality are two important factors in any sustainable human settlement
(Omole et al., 2017; Montgomery, 1995). Potable water supplies in most industrial societies today are regarded as safe because they are treated in one way or the other. This is not the case in the developing or so-called third-world countries, because only a small percentage of the population has access to treated water. The sources of water supply for most rural and urban communities are well water, surface water such as streams, rivers and lakes as well as borehole, dug well and pipe borne water. The chemical, physical and biological characteristics of a water supply depend on many factors, among which are climatic, soil, geologic conditions and human activities that 
result in varying degree of pollution within a drainage basin (Kulkari and Kherede, 2015). The drinking water standards are specified in order to ensure that water meets the designated use, thus water is said to be polluted when it is unfit for its intended use. In Tropical Africa, particularly in Nigeria, these standards are almost impossible to attain in the untreated drinking water supplies serving rural communities. For aesthetic reasons, good quality water is expected to have neutral $\mathrm{pH}$ (7), in addition to being colorless, odorless, and turbid free, while for the health reasons, the water should be free from pathogenic microorganisms and toxic chemicals (IWMI, 2004; SWWA, 2004).

A few machines which treat water by reverse osmosis (RO) and ultra-violet radiation are available in the market. These are meant to reduce to the barest minimum of the contaminants in the water. The RO machine is said to eliminate up to $99 \%$ of dissolved solids, chlorine, fluoride, microorganisms and heavy metals such as barium, cadmium, chromium, lead and mercury from the water. Such RO purified water is used for drinking, cooking and ice for improved flavor health benefits (Bodalo-Santoyo et al., 2003). The UV radiation rays in the range of 10 to $400 \mathrm{~nm}$ units are lethal to all types of bacteria. The UV energy entering the water has no effect on the taste and odor of the water with the exception that certain chemicals will oxidize under the UV light. The taste may change as a result. This oxidation only takes place when the water is standing for a long period of time in front of the UV lamp (Adetayo et al., 2013; Emenike et al., 2018). As of late, researchers focused their study on the layers in other to expel little oil beads, since these techniques require no continuous substitution of channels; therefore, the water quality after treatment is better. However, layers experience the unfavorable effects of fouling as a result of impurities in delivered water. (Dickhout et al., 2017; Matafonova and Batoev 2018 and Zhang et al., 2018).

Water for the populace was often collected from surface and under-ground sources. Different options available for the treatment of water besides Reverse Osmosis and ultra-violet radiation methods include the distiller which uses various forms of primary, secondary and tertiary treatments of wastewater treatment. Its limitations are related to the low production of treated water (Sutherland et al., 2018; Peleato et al., 2018). Nanotechnology holds great potential in advancing water treatment to improve the treatment efficiency as well as to augment water supply through safe use of unconventional water sources; its limitations include the high energy consumption, which is an important barrier to the wide application of pressure-driven membrane processes. Membrane fouling adds to the energy consumption and the complexity of the process design and operation. Photo catalytic technology uses photo catalysts and the UV rays from sunlight to detoxify polluted water at high speeds, creating safe and drinkable water. Its limitations are due to it complex technical barriers that impede its commercialization, remained on the post-recovery of the catalyst particles after water treatment (Ravikumar, and Somashekar 2017).

Reverse osmosis treatment method (RO) is a water purification technology that uses a semi permeable membrane to remove ions, molecules and larger particles from water bodies. Ultra-violet (UV) is an energy band within the electromagnetic energy spectrum. It is a colorless, tasteless, odorless and chemical free way to ensure the water supply is safe and clear of germs and other microorganisms that can make people sick. It works by exposing microorganisms (such as cryptosporidium, guardian lamblia and more) to UV radiation, via a special UV light bulb, which disrupts their DNA and disables their ability to replicate. The proper management of water resources has become the need of the hour as this would ultimately lead to a cleaner and healthier environment. In order to achieve this goal, proper control measures will be discussed.

This research applies the reverse osmosis and ultraviolet radiation water treatment techniques in Omoku Community River in North West Nigeria and underground water (bore-hole), to determine the effectiveness of both method and to also ensure the safety of the people in the community.

\section{MATERIALS AND METHOD}

The study area is Omoku community in River State lies with latitude $5^{\circ} 13^{1} \mathrm{~N}$ and $5^{\circ} 22^{1} \mathrm{~N}$ and longitude $6^{\circ} 33^{1} \mathrm{E}$ and $6^{\circ} 42^{1}$ North West of the Niger Delta region of Nigeria (UNDP, 2006). It is one of the onshore oil producing area of Rivers state, the area which is one of the highest oil and gas producers onshore of Niger Delta has over Nine hundred oil wells with over thirteen active oil fields, playing a host to three multinational companies (Dirisu et al., 2016). 


\section{Samples Collection and Treatment}

The borehole water selected for the study is shown in Table 1, where 1,2 and 3 are the three boreholes.

Collection method: A sterile sampling bottle was used to collect the water samples from these boreholes. The boreholes were switched on and discharge pipes to the reservoir tank was disconnected to allow the water to flow out for minimum period of 5 mins before the raw water was collected on a 4 liter jerry-can with laboratory sanitized standard, and the samples were collected before getting to reservoir tank (GP tank-overhead tank). These procedures were applied to all three Borehole selected at different locations, about 3 kilometres apart within the Omoku town. Secondly, the raw water was redirected to the RO and UV machine for treatment and the treated water was sent to the Laboratory for the physicochemical test which will be compared to the raw result.

For Surface Flowing Water sample: Raw water (Surface flowing water - SFW - 1, 2 and 3) 4 liter sterile sampling bottles were used to collect the water samples from Orashi flowing River at three (3) different points of at least 7 kilometre apart, using the method of sweeping against the flowing river (Stella-Maris, 2001). Each of the collected 4 liter samples were sent to the Laboratory separated into 4 samples of 1 liter each, including: sample 1: raw test, sample 2: RO treated, sample 3: UV treated and reserved) for all physicochemical parameters, respectively.

\section{Laboratory Analysis and Methods}

The water samples were taken for laboratory analysis at NAOC Industrial lab for various physicochemical characteristics and Coliform count. The physicochemical parameters investigated and the methods are shown in Table 2.

Physicochemical Characterization: The water samples were analyzed to determine their physicochemical characteristics. The parameters characterized include $\mathrm{pH}$, electrical conductivity, temperature, total hardness, turbidity, total dissolved solids, total suspended solids, Nutrients such as Nitrate, Sulphate and Chloride, mineral elements such as potassium, sodium and magnesium as well as heavy metals such as Iron, Lead, Chromium and Arsenic.

- Heavy Metals: A measured quantity of the sample was transferred into a Kjeldahl flask; $20 \mathrm{ml}$ of concentrated nitric acid $\left(\mathrm{HNO}_{3}\right)$ was added and the sample pre-digested by heating gently for 10 mins. Afterwads, $10 \mathrm{ml}$ of acid was added and digestion was continued for 30-40 mins. Digestion was stopped when a clear digest was obtained by viewing through a microscope. The flask was cooled and the content transferred into a $50 \mathrm{ml}$ volumetric flask and made to mark with distilled water. The resulting solution was analyzed for heavy metals using an Atomic Absorption Spectrometer (AAS) (Mohammad et al., 2013)

- Salinity (as Chloride): The salinity of the sample was determined as chloride using ASTM D512 titrimetric method. A measured quantity of the sample containing mixed indicator was titrated with Mercury nitrate to an end-point blue-black color. The obtained result was further confirmed electrometrically using a Salinity meter and probe.

- Total Suspended Solids (TSS): The TSS was determined using APHA 2540D (TSS dried at $\left.103-108^{\circ} \mathrm{C}\right)$. A measured quantity of the homogenized sample was filtered. The preweighed filter now containing the suspended solids was then dried for about $1 \mathrm{hr}$ at 103$108^{\circ} \mathrm{C}$ in an oven and weighed. The drying and weighing processes were carried out repeatedly until a constant weight was obtained. The milligram TSS per liter of the sample was calculated by weight difference.

- Sulphate: The sulphate concentration in the samples was determined using DR2800 Spectrophotometer- $\mathrm{SO}_{4}^{2-} \mathrm{D}$ Gravimetric method. The sample was heated with slow addition of Barium Chloride until precipitation was complete. Precipitate was digested at $80-90^{\circ} \mathrm{C}$ for at least $2 \mathrm{hrs}$. The $\mathrm{BaSO}_{4}$ precipitate was fil-

Table 1. Borehole water sampling sites

\begin{tabular}{|c|l|c|c|}
\hline Borehole No. & \multicolumn{1}{|c|}{ Borehole address/location } & \multicolumn{1}{|c|}{$\begin{array}{c}\text { Year } \\
\text { drilled }\end{array}$} & Depth \\
\hline $\mathrm{BH}_{1}$ & $\# 30$, Elder Mark Street, Omoku Rivers State & 2006 & 25 meters \\
\hline $\mathrm{BH}_{2}$ & $\# 18$, Obikeze Street, Omoku Rivers State & 2008 & 35 meters \\
\hline $\mathrm{BH}_{3}$ & $\begin{array}{l}\# 98, \text { Delta Hotels Ltd Along Ahoad Rd, Omoku } \\
\text { Rivers State }\end{array}$ & 2010 & 40 meters \\
\hline
\end{tabular}


Table 2. List of laboratory analytical methods

\begin{tabular}{|c|c|}
\hline Parameter & Method \\
\hline $\mathrm{pH}$ & ORION 1260 \\
\hline Salinity as in (chloride) mg/l & APHA $4500-C L^{-c}$ \\
\hline Total hardness as $\mathrm{CaCO}_{3}, \mathrm{mg} / \mathrm{l}$ & AHPA 2340C \\
\hline 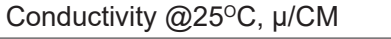 & Electrometric \\
\hline Temperature $\left({ }^{\circ} \mathrm{C}\right)$ & $\begin{array}{l}\text { Thermometric } \\
\text { Determination }\end{array}$ \\
\hline Total dissolved solids, ppm & TDS METRE \\
\hline Turbidity NTU/FTU & 2100 T-METRE \\
\hline $\begin{array}{l}\text { Total suspended solids (TSS), } \\
\text { ppm }\end{array}$ & APHA 2540D \\
\hline Nitrate, Sulphate, mg/l & $\begin{array}{l}\text { DR2800 } \\
\text { Spectrophotometer }\end{array}$ \\
\hline Chloride & ASTM D512 Titrimetric \\
\hline $\begin{array}{l}\text { Potassium, Magnesium, Iron, } \\
\text { Manganese, Lead, Sodium, } \\
\text { Heavy Metals (e.g. Cadmium, } \\
\text { Arsenic and Chromium (mg/l) }\end{array}$ & AAS \\
\hline Coliform & MMO-MUG \\
\hline
\end{tabular}

tered, dried and weighed. Milligram Sulphate per Litre of sample was then calculated.

- Nitrate: The nitrate concentration in the samples was determined using APHA 4500- $\mathrm{NO}_{3}$ $B$ method. Hydrochloric acid was added to the samples. A UV Spectrophotometer set at the various recommended wavelengths $(10-400 \mathrm{~nm})$ was then used to measure the absorbance of the samples, nitrate calibration standards and re-distilled water blank. The nitrate concentration was determined after the requisite calculations from the calibration curve (APHA, 2005)

The parameters in the table below are taken directly with their digital instruments

\section{Statistical Analysis}

The data obtained was subjected to a descriptive and two-way analysis of variance (ANOVA) statistics to test the significant difference in the effectiveness of the RO and UV water treatment in both the borehole (BH) and surface water (SW)

Table 3. Instrumentation

\begin{tabular}{|l|l|}
\hline \multicolumn{1}{|c|}{ Parameter } & \multicolumn{1}{c|}{ Instrument } \\
\hline $\mathrm{pH}$ & Orion Model 1260 Digital \\
\hline Temperature (o C) & $\begin{array}{l}\text { Thermometric } \\
\text { Determination }\end{array}$ \\
\hline Conductivity @ $25^{\circ} \mathrm{C}, \mu / \mathrm{CM}$ & Electrometric \\
\hline Turbidity NTU/FTU & 2100 T-Metre \\
\hline Total suspended solids $(\mathrm{ppm})$ & Electrometric \\
\hline Total dissolved solids. $(\mathrm{ppm})$ & TDS Metre \\
\hline
\end{tabular}

at $95 \%$ confidence limit. This statistical tool was employed due the following reason: The two-way ANOVA compares the mean differences between groups that have been split on two independent variables (called factors). The primary purpose of a two-way ANOVA is to check if there is an interaction between the two independent variables on the dependent variable: RO and UV (independent variables) and water sources: Borehole and surface flowing water. The interaction term in a twoway ANOVA informs whether the effect of one of your independent variables on the dependent variable is the same for all values of the other independent variable and vice versa (Cortina, 2000).

\section{RESULT AND DISCUSSION}

The laboratory results of the treated and untreated (control) water samples - borehole $(\mathrm{BH})$ and surface water (SW) are presented graphically using mean \pm standard deviation values according to each determined physicochemical and biological characteristic. A 2-way ANOVA statistic reported a significant difference between water samples and water treatment method - reverse osmosis (RO) and ultra-violet (UV) as well as the interactions between samples and treatment method.

\section{Effect of water treatment on borehole and surface water $\mathrm{pH}$}

Mean and standard deviation of water samples $\mathrm{pH}$ were $6.52 \pm 0.029,6.76 \pm 0.197$ and $6.15 \pm 0.132$ for borehole water $(\mathrm{BH})$ treated with reverse osmosis (ROT), ultra- violet (UVT) and control (CTRL), respectively, while the surface water mean $\mathrm{pH}$ were $6.33 \pm 0.580,6.41 \pm 0.51$, and 6.6+0.53, shown in Figure 1, respectively. Two-way analysis of variance (ANOVA) statistic indicted that there was no significant difference in the $\mathrm{pH}$ of the water samples with and without treatment, $\mathrm{F}(1,12)=0.019, \mathrm{p}>0.05$ and treatment method, $\mathrm{F}(2,12)=0.449$. The interactions between sample types and treatment were also insignificant, $F(12,17)=1.763, p>0.05$

The borehole water treated with reverse osmosis (ROT), ultra- violet (UVT) and control (CTRL) was slightly acidic in all cases $(\mathrm{pH}$ : $6.52,6.76,6.15$ ) for borehole water as well as the surface water (pH: 6.33, 6.41, 6.6). It does appear that the treatment produced a slight increase in water $\mathrm{pH}$ compared to the control that 


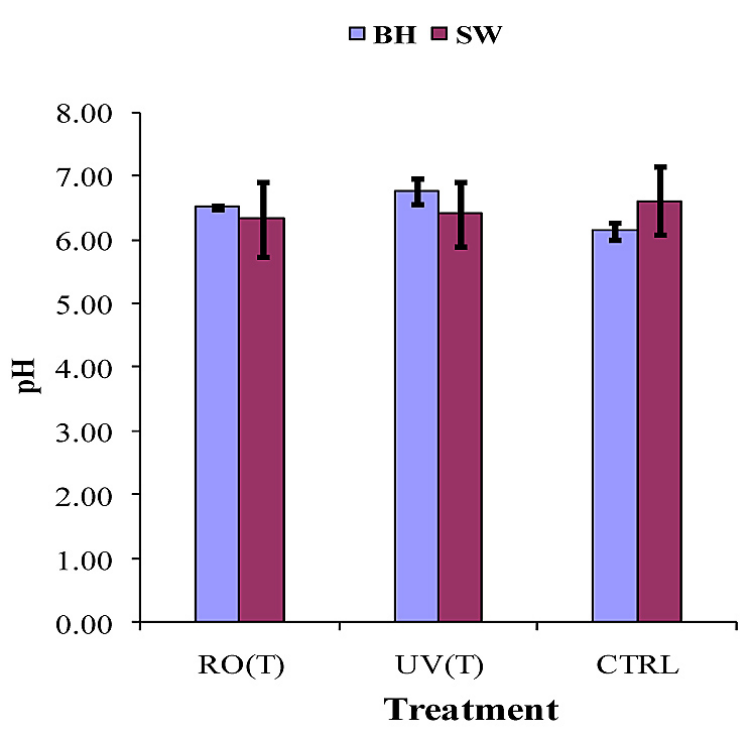

Figure 1. The $\mathrm{pH}$ of water samples treaed with reverse osmosis $(\mathrm{RO}(\mathrm{T})$ and ultra-violet radiation $(\mathrm{RO}(\mathrm{T})$

is $6.15<6.52<6.76$ ), whereas the surface water $\mathrm{pH}$ reduced from 6.6 to 6.3 and 6.4. This may be attributed to the removal of acidifying minerals (Sieliechi et al., 2010). ROT produced BW with reduced acidity than the control (6.52), and UVT tending towards alkaline (6.8) when compared with the untreated SW (6.2). On the other hand, RO seems to produce SW which was slightly more acidic (6.3) than UV (6.41) when compared with the untreated SW (6.6). The $\mathrm{pH}$ values are within the WHO permissible limit of 6.5-7.5.

Removing the minerals makes the water acidic (often $\mathrm{pH}$ well below 7.0). Drinking acidic water will not help maintain a healthy $\mathrm{pH}$ balance in the blood, which should be slightly alkaline. The health impacts of water with low $\mathrm{pH}$ have been confirmed by W.H.O/UNICEF (2005). The RO water is unhealthy because of the demineralization. The water with low $\mathrm{pH}$ produces acidosis (Haern, 2010) which affects the digestive enzymes. Additionally, acidic water has metallic taste, corrodes materials and leads to damage of valuable products (USEPA, 2013; Dirisu et al. 2016).

\section{Effect of water treatment on temperature of borehole and surface water}

From Figure 2, the recorded Temperature $\left({ }^{\circ} \mathrm{C}\right)$ of water were $32.67 \pm 0.577,30.67 \pm 1.155$ and $31.33 \pm 0.577$ for the borehole water $(\mathrm{BH})$ treated with reverse osmosis RO $(\mathrm{T})$, ultra- violet UV (T) and control (CTRL), while the mean temperatures of surface water were $33.77 \pm 1.595$, $31.67 \pm 1.53$, and $32.31 \pm 1.61$, as shown Figure 2. Two-way ANOVA statistic indicted that there was no significant difference in the temperature of the water samples with and without treatment, $\mathrm{F}(1,12)=2.021, \mathrm{p}>0.05$. Tht treatment methods produced a significant difference in the temperature of the water samples, $F(2,12)=0.016$. However, the interactions between sample types and treatment were also insignificant, $\mathrm{F}(12,17)=$ $0.739, p>0.05$. Water treatment using RO and UV did not significantly affect the temperature of the water, irrespective of the source. The temperature values are between $31-33^{\circ} \mathrm{C}$. For the fact that RO systems dispense either cold, hot and or tepid water does not necessarily matter as it is the choice of the user. It is rather the temperatures of the operating RO machines (as well as the water pressure ,among others) that affect the treated water quality (Gedam et al., 2012)

\section{Effect of water treatment on Water Conductivity}

Water conductivities were $40.33 \pm 2.52$, $41.67 \pm 1.53$ and $42.40 \pm 0.53$ for the borehole water $(\mathrm{BH})$ treated with reverse osmosis (ROT), ultra-violet (UVT) and control (CTRL). On the other hand, the values of surface water mean conductivity were $425.07 \pm 315.38,701.60 \pm 244.75$, and 800.0 \pm 246.22 , showed in Figure 3. Two-way ANOVA of variance statistic indicted that there was no significant difference in the conductivity

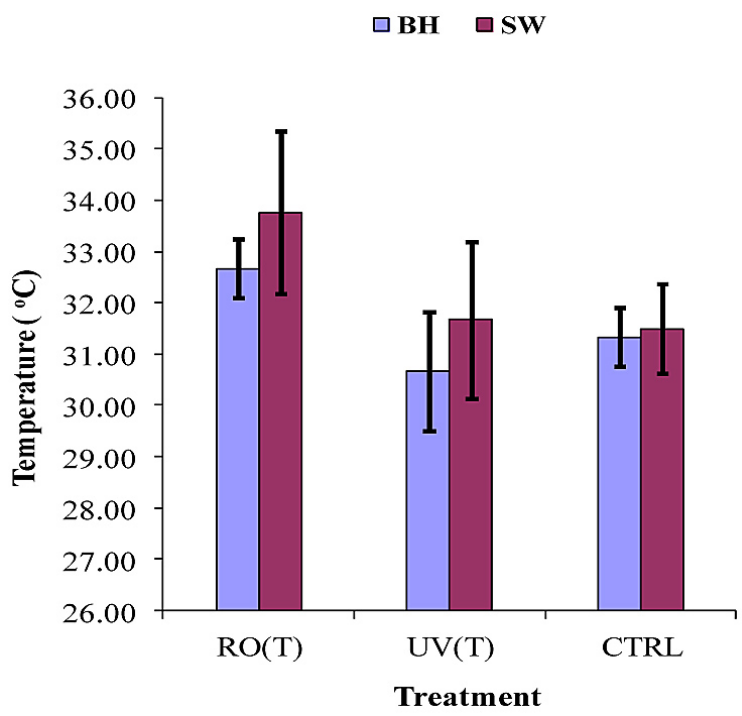

Figure 2. Temperature of water samples treated with reverse osmosis, RO (T) and ultra-violet radiation, UV (T) 
of the water samples with and without treatment, $\mathrm{F}(1,12)=44.29, \mathrm{p}<0.05$ and treatment method, $\mathrm{F}(2,12)=1.56, \mathrm{p}>0.05$. The interactions between the sample types and treatment was not significant, $F(12,17)=1.529, \mathrm{p}>0.05$.

The RO treatment produced demineralized drinking water (Hearn, 2010) with the conductivity ranging from $40<41<423 \mu \mathrm{s} / \mathrm{m}$ for BHW and $<425<701<8003 \mu \mathrm{s} / \mathrm{cm}$ as seen in Figure 3. The value was lower than those reported for ground water, indicating a reduction from 1070 to $33 \mu \mathrm{s} /$ $\mathrm{cm}$, a $95 \%$ reduction is in line with the findings of Belkacem et al., (2007). However, the conductivity values obtained were within the WHO limit of $<20003 \mu \mathrm{s} / \mathrm{cm}$. Water conductivity is a measure of the capability of water to pass electrical flow. This ability is directly related to the concentration of ions in the water.

\section{Effect of water treatment on Turbidity of borehole and surface water}

As shown in Figure 4, the Turbidity (NTU) of the treated and untreated borehole water was beyond the detectable limit (0.00001) while the surface water turbidity was $12.00 \pm 4.36,27.41 \pm 5.37$, and $27.28 \pm 5.51$.

Two-way ANOVA statistic indicted that there was a significant difference in the turbidity of water samples, $F(1,12)=170.62, p<0.05$ and the treatment method, $\mathrm{F}(2,12)=9.033, \mathrm{p}<0.05$. The interactions between sample types and treatment was also significant, $F(12,17)=9.032, p<0.05$. Turbidity values of the $\mathrm{BH}$ water treated with $\mathrm{RO}$ and UV were below detectable limit, while SW had turbidity ranging from $12<27.4<27.28$ NTU, shown in Figure 4. This value is higher than the WHO limit of $<5.00 \mathrm{NTU}$. Water turbidity depends on the source. Belkacem et al. (2007) reported the RO-treated ground water of low turbidity with a reduction from 1.3 to $0.167 \mathrm{NTU}$, which amounts to $97-98 \%$ reduction.

\section{Effect of water treatment on Total Suspended Solid (TSS) of borehole and surface water}

The TSS $(\mathrm{g} / \mathrm{ml})$ of untreated and treated borehole water was insignificant $(0.00007 \pm 0.0$, $0.00001 \pm 0.0$ and $0.00003 \pm 0.0)$ but the SS of $\mathrm{RO}(\mathrm{T}), \mathrm{UV}(\mathrm{T})$ and CTRL surface water were $9.08 \pm 1.233,46.43 \pm 4.14$, and $43.57 \pm 4.524$, respectively, as presented in Figure 5. Two-way ANOVA statistic indicted that there was significant difference in the TSS of the water samples

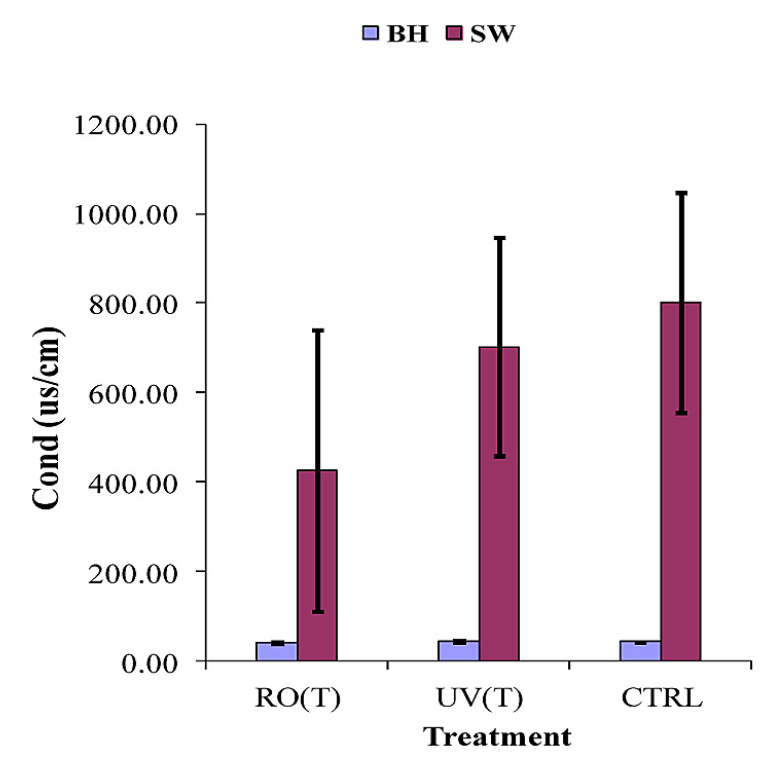

Figure 3. Conductivity of the water samples treated with reverse osmosis RO (T) and ultra-violet radiation UV (T)

with and without treatment, $\mathrm{F}(1,12)=752.73$, $\mathrm{p}<0.05$ and treatment method, $\mathrm{F}(2,12)=99.38$, $\mathrm{p}<005$. There was a significant interaction between the sample types and treatment method, $F(12,17)=99.38, p<0.05$. The TSS of the ROtreated water were insignificant for both BHW $(<0.0001)$ but high in UV-treated SW $(9.08$ $<43.6<46.4)$ for RO, Control and UV treatment. This value is more than the WHO permissible limit of $<5.00$. The result agrees with the reports of insignificant amounts of solutes and TSS (Belkacem et al., 2006).

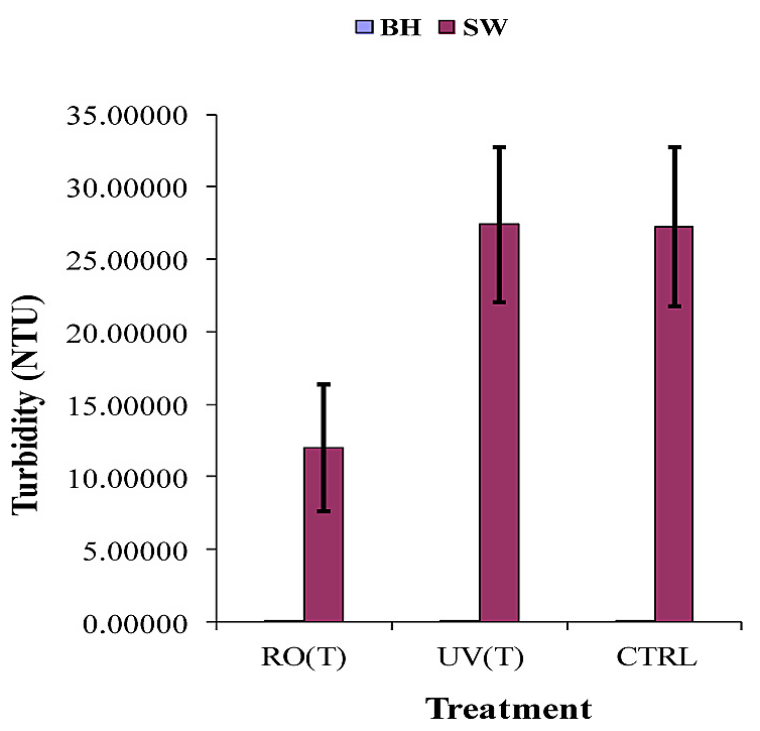

Figure 4. Turbidity $(\mathrm{g} / \mathrm{ml})$ of the water samples treated with reverse osmosis $(\mathrm{RO}(\mathrm{T})$ and ultra-violet radiation $(\mathrm{UV}(\mathrm{T})$ and control 


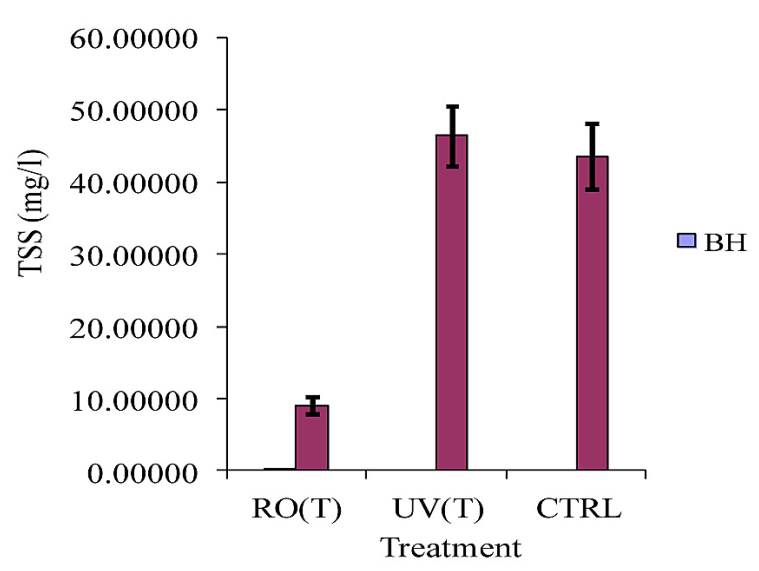

Figure 5. Total Suspended Solids (TSS) $(\mathrm{g} / \mathrm{ml})$ of the water samples treated with reverse osmosis RO (T) and ultra-violet radiation (UV(T) and control

\section{Effect of water treatment on Total Dissolved Solid (TDS) of borehole and surface water}

Mean TDS values of water were $3.50 \pm 2.60$, $16.67 \pm 2.89$ and $20.71 \pm 8.29$ for the borehole water $(\mathrm{BH})$ treated with reverse osmosis (ROT), ultra- violet (UVT) and control (CTRL) respectively while the surface water mean TDS were $13.67 \pm 5.51,42.06 \pm 2.76$, and $586.66 \pm 185.83$ (Fig. 6). Two-way analysis of variance statistic indicated that there was significant difference in the TDS of the water samples with and without treatment, $\mathrm{F}(1,12)=31.37, \mathrm{p}<0.05$ and treatment method, $F(2,12)=28.22, p<0.05$. Interaction between the sample types and treatment was also significant, $F(12,17)=26.07, p<0.05$.

$\square \mathrm{BH} \square \mathrm{SW}$

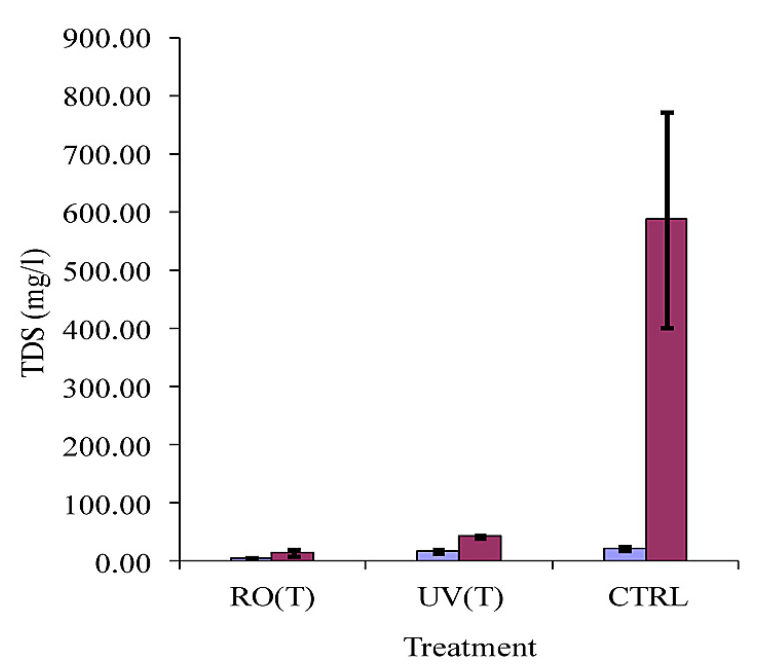

Figure 6. Total Dissolved Solid (TDS) ( $\mathrm{g} / \mathrm{ml}$ ) of water samples treated with reverse osmosis $(\mathrm{RO}(\mathrm{T})$ and ultra-violet radiation (UV(T) and control
The TDS of BHW and SW treated by RO were $3.5<16.7<20.7$ and $13.7<5.51<586.7$ for the UV treated water. RO is well-known for its removal of dissolved nutrients and minerals in the produced water (Kulkarni and Kherede, 2015; Faruk et al. ,2010). The TDS values obtained in this study were within the WHO permissible limit of 0-999 mg/l. When applied to distilling spent mash waste water, RO reduced TDS by $97.9 \%$ (Garud et al., 2011).

\section{Effect of water treatment on salinity of borehole and surface water}

Mean values of water salinity were $11.83 \pm$ $2.75,21.57 \pm 1.21$ and $40.67 \pm 1.16$ for the borehole water $(\mathrm{BH})$ treated with reverse osmosis (ROT), ultra- violet (UVT) and control (CTRL) respectively, while the surface water salinity values were $19.97 \pm 0.58,16.00 \pm 1.00$, and 75.00 \pm 25.00 , respectively, as presented in Figure 7 . Two-way ANOVA statistic indicted that there was no significant difference in salinity of different water samples $F(1,12)=6.42, p>0.05$ but significant difference existed in the treatment method, $\mathrm{F}$ $(2,12)=31.04, p<0.05$. The interaction between the sample types and treatment was also insignificant, $F(12,17)=5.81, p>0.05$.

Salinity is the amount of salts present in water column. There was a reduction of salinity of BHW from $40.7 \mathrm{mg} / 1$ to 11.8 and $21.6 \mathrm{mg} / 1$, following the RO and UV treatment, while SW salinity also

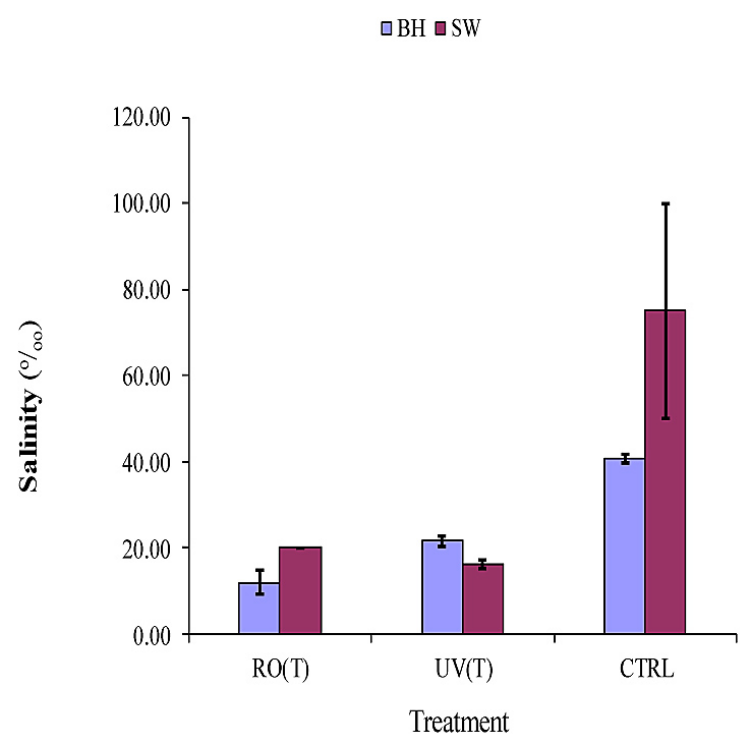

Figure 7. Salinity $(\mathrm{g} / \mathrm{ml})$ of the water samples treated with reverse osmosis, RO $(\mathrm{T})$ and ultra-violet radiation UV (T) and control 
reduced from $75.0 \mathrm{mg} / 1$ to approximately $20 \mathrm{mg} / 1$ in the RO treated water and $16 \mathrm{mg} / \mathrm{l}$ in the UVtreated water. These values are consistent with the general observations that $\mathrm{RO}$ removes minerals from water (Fuqua, 2010; Kulkarni et al, 2015).

\section{Effect of water treatment on Total Hardness of borehole and surface water}

Mean values for total hardness were $0.69 \pm 0.52,1.22 \pm 0.02$ and $2.63 \pm 0.54$ for the borehole water $(\mathrm{BH})$ treated with reverse osmosis (ROT), ultra- violet (UVT) and control (CTRL), respectively, while the values for surface water total hardness were $0.35 \pm 0.56,106.02 \pm 12.96$, and $208.69 \pm 25.00$, respectively.

Two-way ANOVA statistic indicted that there was a significant difference in the salinity of different water samples $F(12,17)=1016.29, p<0.05$ and treatment method, $\mathrm{F}(2,12)=349.53, \mathrm{p}<0.05$. The interaction between sample types and treatment was also significant, $F(12,17)=336.78$, $\mathrm{p}<0.05$. Total hardness equally reduced from 2.63 $\mathrm{mg} / \mathrm{l}$ to 0.69 and $1.2 \mathrm{mg} / \mathrm{l}$ in the RO-treated BHW and UVT water, respectively, while total hardness of SW significantly reduced from 208.7 to 0.35 and $106 \mathrm{mg} / \mathrm{l}$, as shown in Figure 8. However, total hardness in the treated water and control were below the WHO standard of $<250 \mathrm{mg} / \mathrm{l}$. The results show that RO was more effective in removing the substances that causes hardness

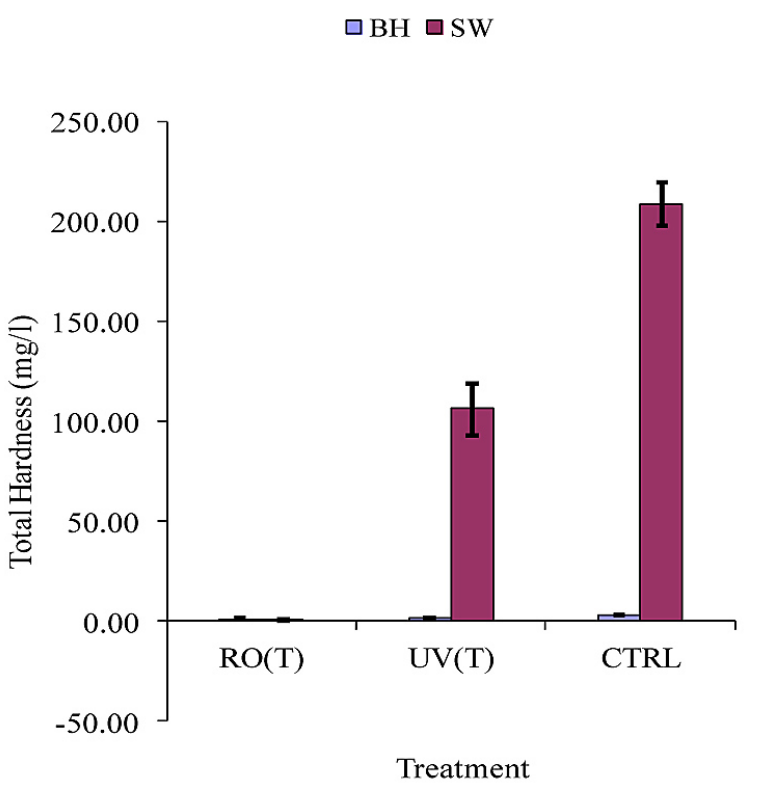

Figure 8. Concentration of Total Hardness $(\mathrm{g} / \mathrm{ml})$ in the borehole and surface water samples treated with reverse osmosis RO (T) and ultra-violet radiation UV (T) and untreated water (CTRL)
(Mohammed et al., 2013). Total hardness is the direct measurement of hardness $\left(\mathrm{Ca}^{2+}+\mathrm{Mg}^{2+}\right)$. Total hardness in drinking water has an important role, since considerable numbers of studies, for example, in the USA, have indicated a correlation between hardness or TDS and mortality, especially the cardiovascular disease (Janna et al., 2016).

\section{Effect of water treatment on nutrients levels of borehole and surface water (Nitrate and Sulphate)}

The mean levels of nitrate ion in water samples were $0.11 \pm 0.012,0.20 \pm 0.095$ and $0.21 \pm 0.105$ for the borehole water $(\overline{B H})$ treated with reverse osmosis (ROT), ultra- violet (UVT) and control (CTRL), respectively, while the surface water had higher mean nitrate level of $126.67 \pm 47.26,29.75 \pm$ 18.21, and 180.42 \pm 26.12 , as presented in Figure 9. Two-way ANOVA statistic showed significant differences in the nitrate concentrations for both water samples, with and without treatment, F (1, $12)=104.50, p<0.05$ and treatment method, $F(2$, $12)=16.15, p<0.05$. There were also significant interactions between the water sample types and treatment, $\mathrm{F}(12,17)=16.16, \mathrm{p}<0.05$.

The concentrations of sulphate ions in the treated and untreated water had mean values of $1.37 \pm 0.55,1.41 \pm 0.62$ and $1.41 \pm 0.62$ for the borehole water $(\mathrm{BH})$ treated with reverse osmosis (ROT), ultra- violet (UVT) and control

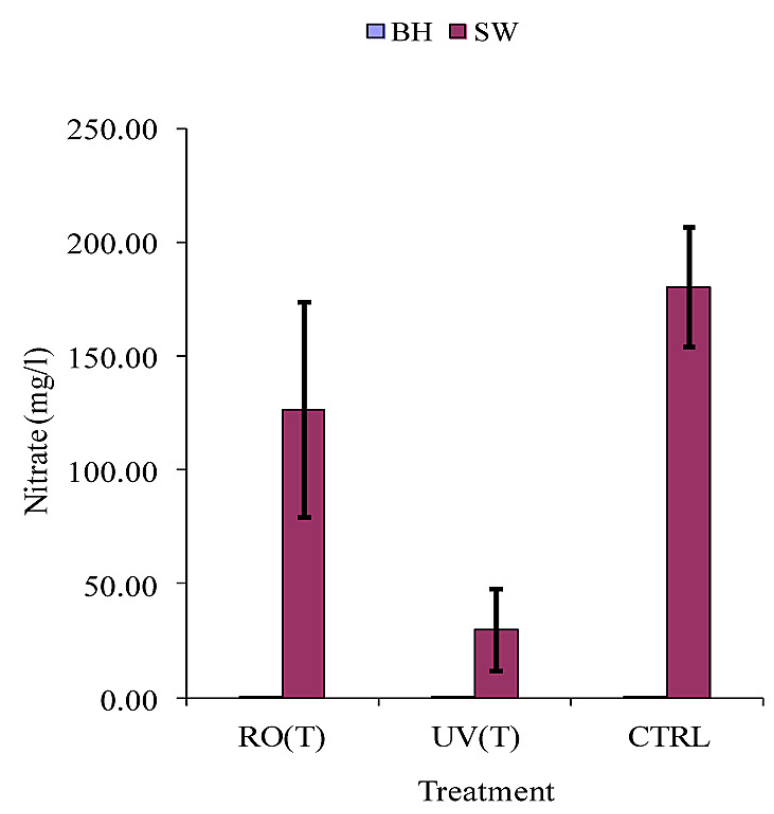

Figure 9. Concentration of nitrate $\left(\mathrm{NO}^{3-}\right)(\mathrm{g} / \mathrm{ml})$ of the water samples treated with reverse osmosis (RO (T) and ultra-violet radiation (UV (T) and control 
(CTRL), respectively, while the surface water had $39.03 \pm 14.88,127.30 \pm 14.88$, and 17.64 \pm 2.51 , on average, as shown in Figure 10.

Moreover, two-way analysis of variance statistic indicted a significant difference in the sulphate levels of the water samples with and without treatment, $\mathrm{F}(1,12)=40.69, \mathrm{p}<0.05$ and treatment method, $\mathrm{F}(2,12)=12.76, \mathrm{p}<0.05$. The interactions between sample types and treatment were also significant, $F(12,17)=12.76, p<0.05$.

The effect of water treatment on nutrients in water always varies depending on the feed water source and geological, as well as human activities around the water source. There were very low nitrate levels in the $\mathrm{BH}$ water treated with $\mathrm{RO}$ and UV $(0.11<0.12)$, as presented in Figure 10 . SW had higher nitrate levels, which were reduced from $180.4 \mathrm{mg} / 1$ to 126.7 and $29.29 \mathrm{mg} / 1$ for RO and UV treatment, respectively. The results also indicated a reduction when compared with the control samples, although all samples were below the $250 \mathrm{mg} / \mathrm{l}$ level permitted by W.H.O (2004a). In a related study, Belkacem et al. (2006) reported a $88.18 \%$ reduction in nitrate for the RO-treated ground water used for beverage industry.

The sulphate levels were lower in the BHW (from $0.62-1.41 \mathrm{mg} / \mathrm{l})$ than SW $(17-127 \mathrm{mg} / \mathrm{l}$ ) (and values were within the WHO permissible limits of $<250 \mathrm{mg} / \mathrm{l}$. Both treatment methods appear to have no reduction effect on the treated water, seen in Figure 10.

$\square \mathrm{BH} \square \mathrm{SW}$

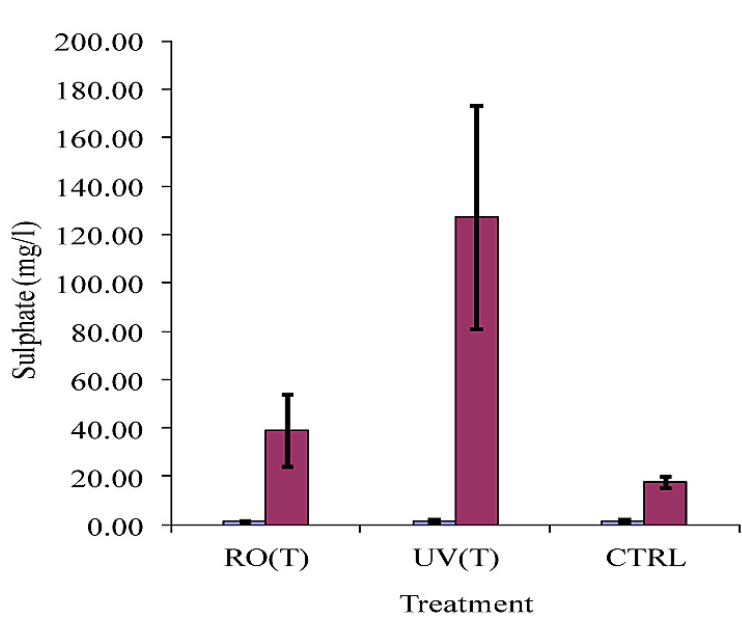

Figure 10. Concentration of sulphate $\left(\mathrm{SO}^{2-}\right)(\mathrm{g} / \mathrm{ml})$ in borehole and the surface water samples treated with reverse osmosis (RO $(\mathrm{T})$ and ultra-violet radiation $(\mathrm{RO}(\mathrm{T})$ and control

\section{Effect of water treatment on the Concentration of mineral elements (Sodium, Potassium) of borehole and surface water}

Mean levels of sodium in water samples were $0.01 \pm 0.00,0.073 \pm 0.01$ and $0.08 \pm 0.01$ for the borehole water $(\mathrm{BH})$ treated with reverse osmosis (ROT), ultra- violet (UVT) and control (CTRL), respectively, while the mean levels of surface water sodium were $34.17 \pm 3.33,19.68 \pm 0.59$ and $36.48 \pm 7.71$, respectively (Figure 11). Two-way analysis of variance statistic indicted that there was a significant difference in the concentration of sodium ion in the water samples with and without treatment, $F(1,12)=3.34, p<0.05$ and the treatment method, $F(2,12)=10.50$. The interactions between the sample types and treatment were also significant, $\mathrm{F}(12,17)=10.51, \mathrm{p}<0.05$.

The concentrations of magnesium in the water samples were $0.01 \pm 0.00,0.33 \pm 0.25$ and 0.06 \pm 0.02 in the borehole water $(\mathrm{BH})$ treated with reverse osmosis (ROT), ultra- violet (UVT) and control (CTRL), respectively, while the surface water mean magnesium levels were $33.00 \pm 8.18$, $20.93 \pm 0.75$, and $40.52 \pm 23.51$, respectively (Figure 12). Two-way analysis of variance statistic indicted that there was no significant difference in the $\mathrm{Mg}$ levels of the water samples with and without treatment, $\mathrm{F}(1,12)=98.17, \mathrm{p}<0.05$ and the treatment method, $\mathrm{F}(2,12)=11.69$. The interactions between the sample types and treatment was also significant, $\mathrm{F}(12,17)=11.86, \mathrm{p}<0.05$.

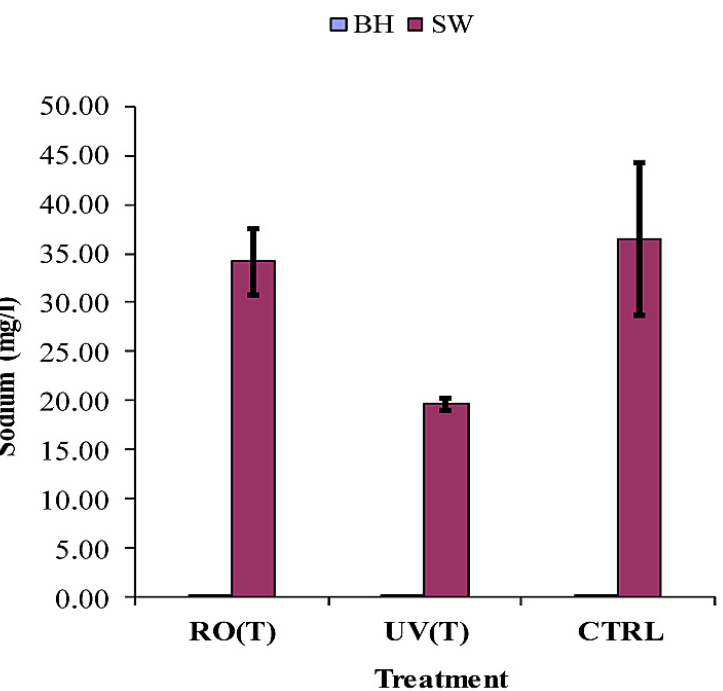

Figure 11. Concentration of sodium $\left(\mathrm{Na}^{+}\right)$ion in the borehole and surface water samples treated with reverse osmosis $(\mathrm{RO})(\mathrm{T})$ and ultra-violet radiation (UV) (T) and untreated water (CTRL) 
The mean levels of potassium ( $\mathrm{K}$ ) in water samples were $0.01 \pm 0.01,1.27 \pm 0.64$ and 2.89 \pm 0.19 for the borehole water $(\mathrm{BH})$ treated with reverse osmosis (ROT), ultra-violet (UVT) and control (CTRL), respectively, while the surface water mean $\mathrm{K}$ levels were $30.54 \pm 1.30,35.00 \pm$ 5.00 , and $56.7 \pm 16.07$, respectively (Figure 13). Two-way analysis of variance statistic indicted that there was significant a difference in the concentrations of $\mathrm{K}$ in the water samples with and without treatment, $\mathrm{F}(1,12)=146.39, \mathrm{p}<0.05$ and the treatment method, $\mathrm{F}(2,12)=7.44$, $\mathrm{p}<0.05$. However, the interactions between the sample types and treatment was not significant, $\mathrm{F}(12,17)=5.00, \mathrm{p}>0.05$.

Mineral elements, such as sodium, magnesium and potassium had significantly reduced levels $(p<0.05)$ in Figures 11-13. This is also consistent with the rationale for the RO treatment, which is aimed at removing or reducing the high mineral content of the feed water (Janna et al., 2016). The result conforms to the high reduction rate in $\mathrm{K}$ ion (94.65\%) (Belkacem et al., 2006); and reduction of magnesium (from 31.2 to between 9.5-18.2) calcium (from 90.3 to between 5.3-25.0) and TH (from $359 \mathrm{mg} / \mathrm{l}$ to between 45.7-134.3) as reported by Mohammed et al., (2013). In general, it can be noticed that the mean concentrations of these constituent were lower than WHO (WHO STD) drinking water standards. Gedam et al. (2012) equally affirmed that RO removes $95 \%$ to $98 \%$ of fluoride, TDS, sulphate, iron and other ground water contaminants under optimized conditions. Different parameters, such as $\mathrm{pH}$, pressure and temperature affect the RO membrane efficiency. Thus, proper control of these factors is essential for a successful operation and maintenance. A RO Membrane generates huge quantity of reject water (i.e. $65-75 \%$ ).

\section{Effect of water treatment on the concentration of Heavy Metals of the borehole and surface water ( $\mathrm{Cd}, \mathrm{Fe}, \mathrm{Pb}, \mathrm{As}$ and $\mathrm{Cr}$ )}

The concentrations of cadmium in water samples were insignificant $(0.00 \pm 0.00)$ for the borehole water $(\mathrm{BH})$ treated with reverse osmosis (ROT), ultra-violet (UVT) and control (CTRL), while the surface water mean $\mathrm{Cd}$ levels were $0.00 \pm 0.00,0.04 \pm 0.04$, and $4.73 \pm 6.40$, respectively (Figure 14). Two-way analysis of variance statistic indicted that there was no significant dif- ference in the Cd levels of the water samples with and without treatment, $\mathrm{F}(1,12)=1.67, \mathrm{p}>0.05$ and the treatment method, $\mathrm{F}(2,12)=1.68$, $\mathrm{p}>0.05$. The interactions between sample types and treatment were also insignificant, $F(12,17)$ $=1.63, \mathrm{p}>0.05$.

The concentrations of Iron $(\mathrm{Fe})$ in the water samples were $0.00 \pm 0.00,0.01 \pm 0.00$, and $0.02 \pm 0.01$ for the borehole water $(\mathrm{BH})$ treated with reverse osmosis (ROT), ultra-violet (UVT) and control (CTRL), while the surface water mean Iron levels were $0.00 \pm 0.00,1.40 \pm 0.17$, and 1.45 \pm 0.18 , respectively (Figure 15 ). Two-way analysis of variance statistic indicted that there was

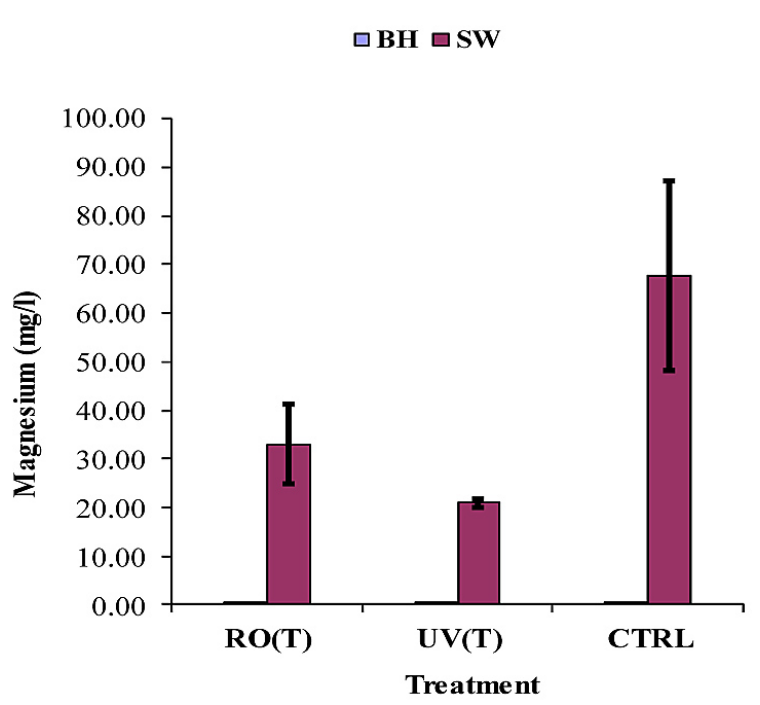

Figure 12. Concentration of magnesium $(\mathrm{Mg})(\mathrm{g} / \mathrm{ml})$ in the borehole and surface water samples treated with reverse osmosis (RO $(\mathrm{T})$ and ultra-violet radiation (UV (T) and untreated water (CTRL)

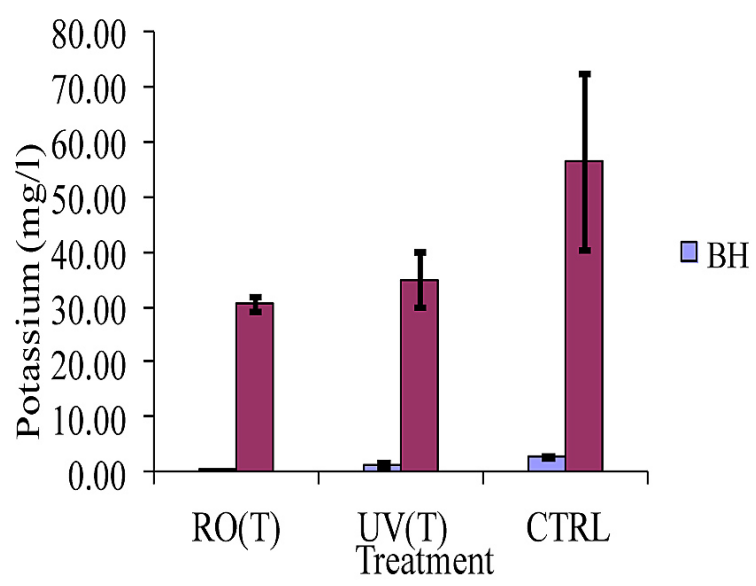

Figure 13. Concentration of potassium $(\mathrm{K})$ ion $(\mathrm{g} / \mathrm{ml})$ in the borehole and surface water samples treated with reverse osmosis (RO $(\mathrm{T})$ and ultra-violet radiation (UV (T) and untreated water (CTRL) 


\section{$\square \mathrm{BH} \square \mathrm{SW}$}

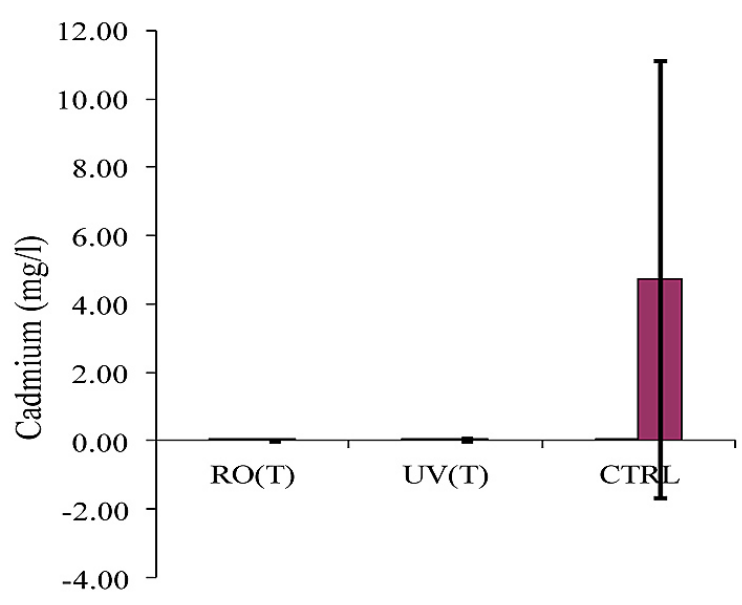

Treatment

Figure 14. Concentration of cadmium $\left(\mathrm{Cd}^{-}\right)(\mathrm{g} / \mathrm{ml})$ in the borehole and surface water samples treated with reverse osmosis (RO $(\mathrm{T})$ and ultra-violet radiation

(UV(T) and untreated water (CTRL)

a significant difference in the Fe levels of water samples with and without treatment, $F(1,12)=$ $378.78, \mathrm{p}<0.05$ and the treatment method, $\mathrm{F}(2$, $12)=98.41, p<0.05$. The interactions between the sample types and treatment were also significant, $\mathrm{F}(12,17)=94.76, \mathrm{p}<0.05$.

The concentrations of $\mathrm{Pb}$ in the water samples were insignificant $(0.00 \pm 0.00)$ for all borehole water $(\mathrm{BH})$ treated with reverse osmosis (ROT), ultra- violet (UVT) and control (CTRL), while the surface water $\mathrm{Pb}$ levels were $1.03 \pm 0.50,4.90 \pm$ 0.62 , and $16.17 \pm 1.07$, respectively (Figure 16). Two-way analysis of variance statistic indicted that there was a significant difference in the $\mathrm{Pb}$ levels of water samples with and without treatment, $\mathrm{F}(1,12)=245.8, \mathrm{p}<0.05$ and the treatment method, $\mathrm{F}(2,12)=36.02, \mathrm{p}<0.05$. The interactions between sample types and treatment were also insignificant, $\mathrm{F}(12,17)=36.02, \mathrm{p}<0.05$.

The concentrations of arsenic in the water samples were insignificant $(0.00 \pm 0.00)$ for all borehole water $(\mathrm{BH})$ treated with reverse osmosis (ROT), ultra-violet (UVT) and control (CTRL), while the surface water as levels were $0.34 \pm 0.56$, $0.49 \pm 0.51$, and $10.77 \pm 0.63$, respectively (Figure 17). Two-way analysis of variance statistic indicted that there was a significant difference in the As levels of water samples with and without treatment, $F(1,12)=6.34, p<0.05$ and the treatment method, $F(2,12)=0.34, p>0.05$. The interactions between the sample types and treatment was also insignificant, $F(12,17)=0.34, \mathrm{p}>0.05$. $\square \mathrm{BH} \square \mathrm{SW}$

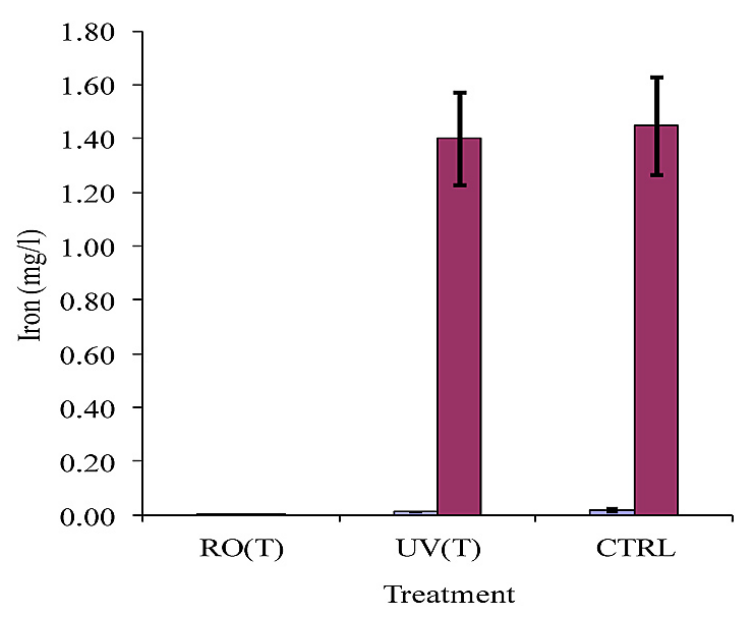

Figure 15. Concentration of iron $(\mathrm{Fe})(\mathrm{g} / \mathrm{ml})$ in the borehole and surface water samples treated with reverse osmosis $(\mathrm{RO})(\mathrm{T})$ and ultra-violet radiation (UV(T) and untreated water (CTRL)

The concentrations of $\mathrm{Cr}$ in the water samples were insignificant $(0.00 \pm 0.00)$ for all borehole water $(\mathrm{BH})$ treated with reverse osmosis (ROT), ultra- violet (UVT) and control (CTRL), while the surface water mean levels were $0.34 \pm 0.58,7.14$ \pm 1.65 , and $9.19 \pm 0.74$, respectively (Figure 18).

Two-way analysis of variance statistic indicted that there was a significant difference in the $\mathrm{Cr}$ levels of water samples with and without treatment, $\mathrm{F}(1,12)=230.6, \mathrm{p}<0.05$ and the treatment

$\square \mathrm{BH} \square \mathrm{SW}$

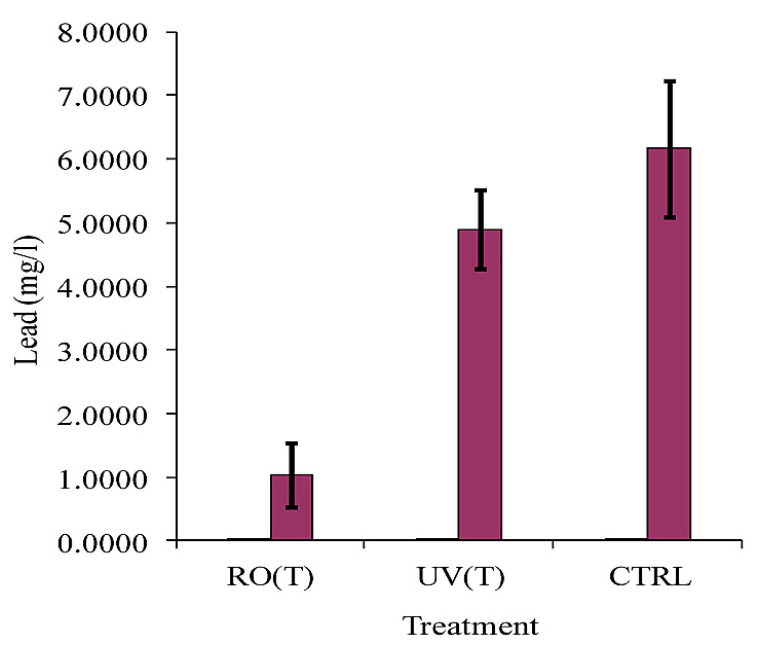

Figure 16. Concentration of lead $(\mathrm{Pb})(\mathrm{g} / \mathrm{ml})$ in the borehole and surface water samples treated with reverse osmosis (RO $(\mathrm{T})$ and ultra-violet radiation (UV (T) and untreated water (CTRL) 


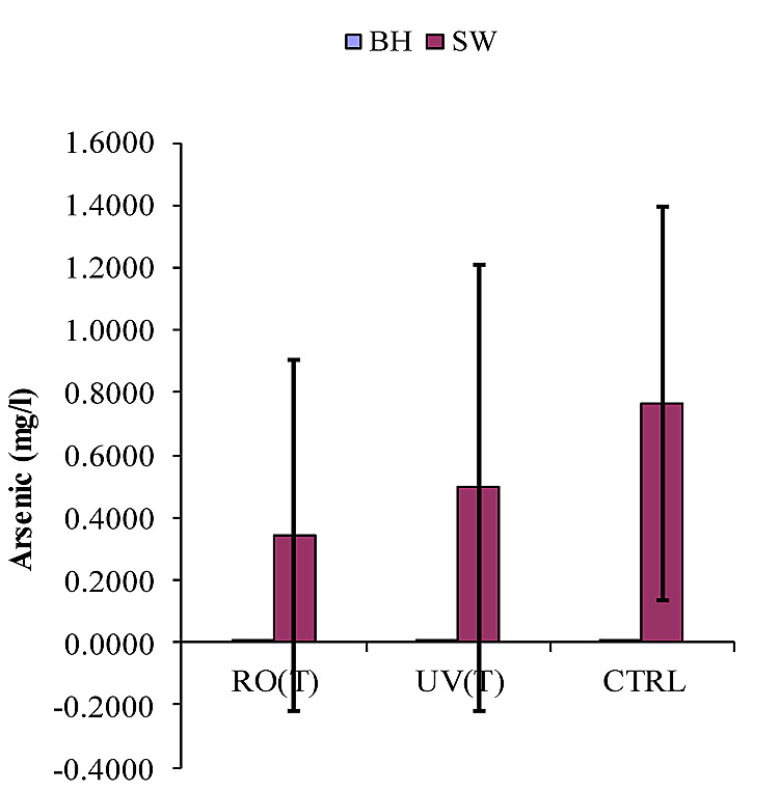

Treatment

Figure 17. Concentration of arsenic (As) $(\mathrm{g} / \mathrm{ml})$ in the borehole and surface water samples treated with reverse osmosis (RO $(\mathrm{T})$ and ultra-violet radiation

(UV (T) and untreated water (CTRL)

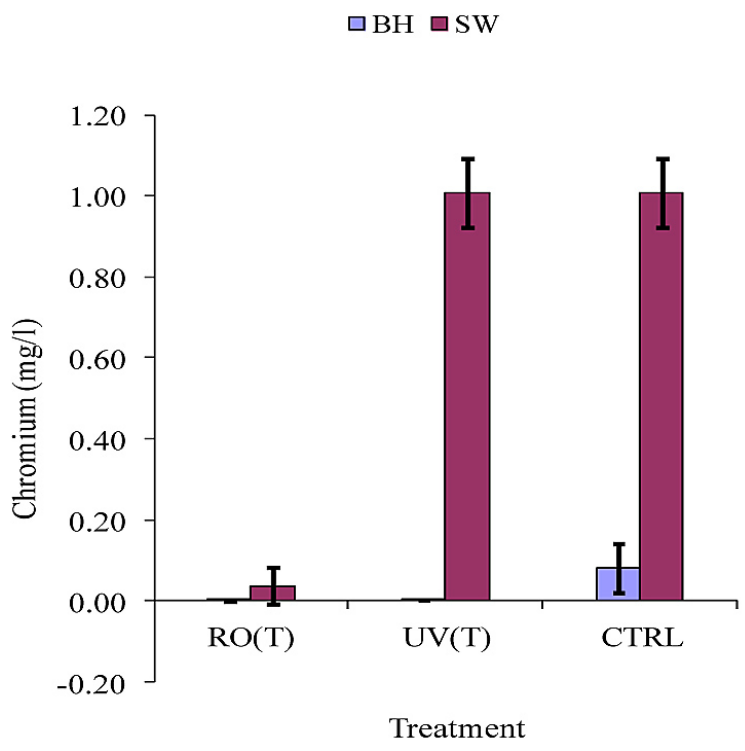

Figure 18. Concentration of chromium $(\mathrm{Cr})(\mathrm{g} / \mathrm{ml})$ in the borehole and surface water samples treated with reverse osmosis ( $\mathrm{RO}(\mathrm{T})$ and ultra-violet radiation

(UV (T) and untreated water (CTRL)

method, $\mathrm{F}(2,12)=53.47, \mathrm{p}<0.05$. The interactions between the sample types and treatment was also significant, $\mathrm{F}(12,17)=53.47, \mathrm{p}<0.05$.

Heavy metals in drinking water can cause various health effects on humans and animals (Kulkarni and Kherede, 2015). The concentrations of heavy metals in the treated water were as follows: Cd not detected $(<0.0001)$ except for control in surface water where levels were up to $4.73 \mathrm{mg} / \mathrm{l}$; the Fe levels ranged from nil $(<0.001)$ to $1.45 \mathrm{mg} / 1$; the $\mathrm{Cu}$ levels were significantly, high ranging from 0.001 in $\mathrm{RO}(\mathrm{T})$ to 0.27 in $\mathrm{UV}(\mathrm{T})$ in BHW and from 0.36 to 3.61 in the surface water treated. The arsenic level in BHW was extremely low compared to the level in the treated surface water. Lead was not detected in BHW but had the level ranging from 1.3 to 4.9 in RO (T) and UV (T) water. The health effects of heavy metals in drinking water have been reported by several authors (Hearn, 2010) For example, exposure to the arsenic levels as low as $50 \mu \mathrm{g} / \mathrm{L}(0.05 \mathrm{mg} / \mathrm{l})$ cause skin lesions (Mcdonald, 2007). The arsenic ingestion causes characteristic pigmentation changes in the skin of the trunk and limbs and nodular keratosis on the palms and soles. Cancers and other disorders have been associated with the consumption of heavy metals in drinking water.

\section{Effect of water treatment on total Coliform in the borehole and surface water}

Total Coliform count in the water samples were insignificant $(<0.0001)$, for the borehole water $(\mathrm{BH})$ treated with reverse osmosis (ROT), ultra-violet (UVT) and control (CTRL), while the surface water total Coliform were $1.07 \pm 0.06$, $11.4 \pm, 1.01$, and $15.00 \pm 0.00$, respectively (Figure 19). Two-way analysis of variance statistic indicted that there was a significant difference in the total Coliform count of water samples with and without treatment, $\mathrm{F}(1,12)=2199.11$, $\mathrm{p}<0.05$ and the treatment method, $\mathrm{F}(2,12)=$ $457.93, \mathrm{p}<0.05$. The interactions between the sample types and treatment was not significant, $\mathrm{F}(12,17)=457.93, \mathrm{p}>0.05$.

There was no Coliform detected in the water samples $(<0.0001)$, for the borehole water $(\mathrm{BH})$ treated with reverse osmosis (ROT), ultra-violet (UVT) and control (CTRL), while the surface water total Coliform count ranged from 1.07MPN/ $\mathrm{ml}-15.00$, as presented Figure 19. RO is reported for its efficiency in removing certain pathogenic microorganisms - bacteria and protozoa, while the UV systems completely destroy them. According to Lehtola et al. (2003), UV irradiation at a wavelength of $253.7 \mathrm{~nm}\left(\mathrm{UV}_{254}\right)$ is commonly used for drinking water disinfection. The authors reported that $90 \%$ of bacteria in drinking water were inactivated with the $\mathrm{UV}_{254}$-irradiation doses below $50 \mathrm{~mW} \mathrm{~s} / \mathrm{cm}^{2}$ while a high dose $\left(501 \mathrm{~mW} \mathrm{~s} / \mathrm{cm}^{2}\right)$ 


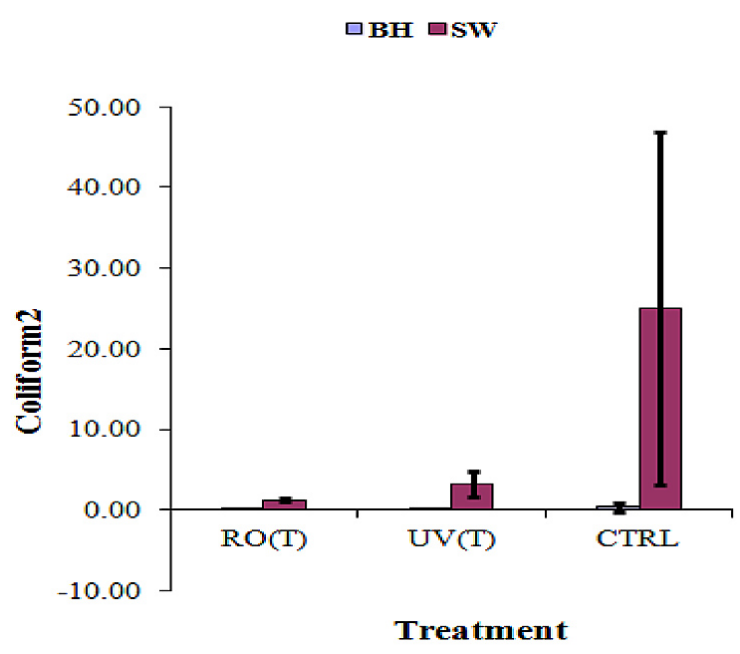

Figure 19. Total Coliform (MPN/100ml) in the borehole and surface water samples treated with reverse osmosis (RO (T) and ultra-violet radiation (UV (T) and untreated water (CTRL)

of $\mathrm{UV}_{254}$ radiation inhibited the microbial growth in water. At sufficiently high doses, all waterborne enteric pathogens are inactivated by the UV radiation. Most low-pressure mercury lamp UV disinfection systems can readily achieve the UV radiation doses of $50-150 \mathrm{MJ} / \mathrm{cm}^{2}$ in high quality water, and - therefore - efficiently disinfect essentially all waterborne pathogens.

In spite of this level of inactivation, the presence of dissolved organic matter, such as natural organic matter, certain inorganic solutes, such as iron, sulphites and nitrites, and suspended matter (particulates or turbidity) tends to absorb the UV radiation or shield microbes from the UV radiation, resulting in lower delivered UV doses and reduced microbial disinfection. Another concern about disinfecting microbes with lower doses of UV radiation is the ability of bacteria and other cellular microbes to repair the UV-induced damage and restore infectivity, a phenomenon known as reactivation. UV light inactivates microorganisms by damaging deoxyribonucleic acid (DNA) and ribonucleic acid (RNA). When DNA and RNA absorb UV light, dimers (covalent bonds between the same nucleic acids) are formed, resulting in damage.

\section{CONCLUSION}

The study attempted to ascertain the effectiveness of reverse osmosis (RO) and ultra violet (UV) radiation on drinking water quality using borehole and surface water as the raw feed water.
The results indicate that RO significantly reduced salt, most other inorganic material present in the water, and some organic compounds. With a quality carbon filter to remove any organic materials that percolate through the filter, the purity of the treated water approaches that produced by distillation. The treated water seemed to have low concentrations of minerals required for maintaining good health. Many factors impact the RO membrane efficiency in reducing the amount of contaminants in the water. These include the water $\mathrm{pH}$, temperature and pressure; the concentration and chemical properties of contaminants as well as the membrane type and condition. UV, on the other hand was effective in disinfecting water by reducing, Coliform bacteria, which are regarded as indicators of faucal contamination of water. UV produced minimal effect on the levels of minerals in the treated water. However, to be effective as water disinfectant, the feed water in the UV systems should be turbid free and devoid of colloidal particles, which could interfere with light transmission in the water column.

\section{REFERENCES}

1. Adah, P.D and Abok G. (2013). Challenges of urban water management in Nigeria: The way forward, Journal of environmental sciences and resource management 5(1): 111-121.

2. Ademoroti, C. A. (1996). Standard methods for water and effluent analysis. Env Chem and toxicol. Foludex Press Ltd., Ibadan. $22-23$.

3. Adetayo, A.O and Aduramigba-Modupe, V.O. (2013). Quality Assessment of Rainwater Harvested through Different Roof Types in Ibadan Metropolis, Nigeria; Sciknow Publications Ltd. ER 1(3):60-63

4. Akhionbare, S.M.O (2008). Appropriate water treatment technologies for rural communities' Environtrend- A magazine of the society of environmental technology Students (SOETS), Federal University of Tech. Owerri, 2 (1):7-9.

5. Allan H. Smith and Craig M. Steinmaus (2009). Health Effects of Arsenic and Chromium in Drinking Water: Recent Human Findings; Annual Rev Public 4, 104-110. http://dx.doi.org/10.4236/ gep.2016.42012

6. APHA [American Public Health Association] (2005). Standard Method of Examination of Water and Wastewater. Washington

7. Belkacem, M; Bekhti, S and Bensadok, K. (2007). Groundwater treatment by reverse osmosis, Desalination 206 (1): 100-106 
8. Bellona, C., J.E. Drewes, P. Xua and G. Amy,(2004):,"Factors affecting the rejection of organic solutes during NF/RO treatment-a literature review, "Water Research, 38: 2795-2809.

9. Bodalo-Santoyo, A., J.L. Gomez-Carrasco, E. Gomez-Gomez, F.Maximo-Martin and A.M. Hidalgo-Montesinos,(2003):,"Application of reverse osmosis membrane to reduce pollutants present in industrial waste water, "Desalination, 155: 101-108.

10. Choi Y and Choi YJ. (2010). The effects of UV disinfection on drinking water quality in distribution systems. Water Res. 44(1):115-22.

11. Cunningham, W.P. and Saigo, B.W. (2001). Environmental Science, 6th Edition: by New York; McGraw -Hill. Companies-Inc.

12. Davison, G. Howard, M. Steens, P. Callen, L. (2005). Managing drinking- water quality from catchment to consumer, water safety plans, WHO, Geneve, pp. 38-45.

13. Department of Water Affairs and Forestry, [DWAF] (2000). http//www.fwr.org/wresa/tt13200.htm.

14. Dickhout, J. M., Moreno, J., Biesheuvel, P. M., Boels, L., Lammertink, R. G., \& de Vos, W. M. (2017). Produced water treatment by membranes: a review from a colloidal perspective. Journal of colloid and interface science, 487, 523-534.

15. Dirisu, C. G; Mafiana, M.O and Dirisu, G.B. (2016). Level of $\mathrm{pH}$ in drinking water of an oil and gas producing community and perceived biological and health implications. European Journal of Basic and Applied Sciences 3(3):53-60 ISSN 2059-3058

16. Dirisu, C.G. (2006). "Acid rain experiments and activities for teaching pollution effects on soil, livestock, fresh water and fishery" STAN Env. Edu. Series No. 10 pp 85-92

17. Duggal, K.N. (2002). Elements of Environmental Engineering: New Delhi; S. Chand and Company Ltd.

18. Edem, B.I. (2011). Effect of gas flaring in Ekeremor area of Bayelsa State, Nigeria. J. Environ. Ecol. 3:38-51.

19. Emenike, C. P., Tenebe, I. T., \& Jarvis, P. (2018). Fluoride contamination in groundwater sources in Southwestern Nigeria: Assessment using multivariate statistical approach and human health risk. Ecotoxicology and environmental safety, 156, 391-402.

20. FAO [Food and Agricultural Organization] (1985). Water Quality for Agriculture, Paper No. 29 (Rev. 1), UNESCO, Publication Rome, www.fao.org/docrep/003/t0234e/t0234e06.htm

21. FGN [Federal Government of Nigeria] (2010). Natural water supply and sanitation policy 1 st edition. Lagos

22. Fuqua, G.W. (2010). A comparative review of water disinfection methods appropriate for develop- ing countries and their efficacy, cost-efficiency, and usability . Texas Medical Center Dissertations (via ProQuest). Paper AAI1479579.

23. Garud R. M., Kore S. V., Kore V. S., Kulkarni G. S. (2011). A Short Review on Process and Applications of Reverse Osmosis, Universal Journal of Environmental Research and Technology, 1(3), 233-238

24. Gauthier, I F., Courchesne, F ;.Pepin, P ; Mortimer, J; Gauvreau, D. (2000). Aluminum forms in drinking water and risk of Alzheimer's disease, Environmental Research, 84(3): 232-246.

25. Gedam, V.V; Patil, J.L; Kagne, S.; Sirsam, R.S; Labhasetwar, P. (2012). Performance Evaluation of Polyamide Reverse Osmosis Membrane for Removal of Contaminants in Ground Water Collected from Chandrapur District. J Memb Sci Technol 2:117.

26. Hearn, N. (2010). Reverse Osmosis Water Health Advantages and Disadvantages Water benefits Health http://www.waterbenefitshealth.com/reverse-osmosis-water.htmlhttps://en.wikipedia.org/ wiki/Reverse_osmosis

27. IWMI [Integrated water management institute] (2004). "Water Quality" Chapter 5. http://www.irli. org/publications/cdrom/integratedwater/IWMI/ Documents/related_doucme...

28. Janna, H; Abbas, M..D. and Mojid, M.H. (2016). Demineralized Drinking Water in Local Reverse Osmosis Water Treatment Stations and the Potential Effect on Human Health. Journal of Geoscience and Environment Protection, 4: 104-110

29. Johnson1, K.M.; Anil Kumar, M.R.; Ponmurugan, P.; and B. Mythili Gananamanga, B. M (2010). Ultra violet radiation and its germicidal effect in drinking water purification; Journal of Phytology, 2(5): 12-19 ISSN: 2075-6240

30. Krantz, D. and Kifferstein, B. (2006). "Water pollution and Society" http://www.umich.edu/ gs265/ society/waterpollution.htm

31. Kulkarni SJ, Kherde PM. (2015). A review on advanced membrane separation methods for water treatment. Int'1 J Res Rev. 2(8):513-517.

32. Kvech, S. Edwards, M. (2002). Solubility controls on aluminum in drinking water at relatively low and high pH, Water Resources 36: 4356-4368.

33. Lehtola, M.J. Nissinen, T. K. Miettinen T.I. (2004). Removal of soft deposits from the distribution system improves the drinking water quality, Water Research, 38: 601-610.

34. Lehtola, M.J; Rantakokko, P; Hirvonrn, A and Martikainen, P.J (2003). Impact of UV disinfection on microbially available phosphorus, organic carbon, and microbial growth in drinking water, Water Research 37(5), 1064-1070

35. Li, H., Li, S., Tang, W., Yang, Y., Zhao, J., Xia, S., 
... \& Wang, H. (2018). Influence of secondary water supply systems on microbial community structure and opportunistic pathogen gene markers. Water research, 136, 160-168.

36. Matafonova, G., \& Batoev, V. (2018). Recent advances in application of UV light-emitting diodes for degrading organic pollutants in water through advanced oxidation processes: A review. Water research.

37. McDonald C, Hogue R, Huda N, Cherry N. (2007). Risk of arsenic-related skin lesions in Bangladeshi villages at relatively low exposure: a report from Gonoshasthaya Kendra. Bull. World Health Organization 85:668-673

38. Mohammad, M.S., Ali, A.H., Tarik, N.K., Enas, M.A., Buthaina, Y.M. and Mahasin, A.A. (2013). Comparison of Total Hardness, Calcium and Magnesium Concentrations in Drinking Water (RO), and Municipal Water with W.H.O and Local Authorities at Basrah Province, Iraq. Marsh Bulletin, $8: 65-75$.

39. Montgomery, C. W. (1995). Environmental Geology. (Northern Illinois University 4th Edition (Gatherines Di Pasquale (Ed.)

40. Murthy, G.V.P, and Choudhari, L.B, (2009). "Treatment Of Distillery Spent Wash By Combined Ultra-filtration And Reverse Osmosis Processes", Global NEST Journal, 11(2):235-240.

41. Nataraj S.K., Hosamani K.M. and Aminabhavi T.M., (2006): Distillery wastewater treatment by the membrane-based Nanofiltration and reverse osmosis processes, Water Research, 40:2349- 2356.

42. Nigerian Standard for Drinking Water Quality (2007): Nigerian Industrial Standard, NIS 554 with Standard Organization of Nigeria (SON).

43. Okonkwo. U. C. (2012).The Engineer: Professionalism in Society. Akwa: Scoa Heritage Systems.

44. Omole, D. O., Alade, O. O., Emenike, P. C., Tenebe, I. T., Ogbiye, S. A., \& Ngene, B. U. (2017). Quality Assessment of a University Campus Wastewater
RESOURCE. WIT Transactions on Ecology and the Environment, 216, 193-201.

45. Pacini, V.A., Ingallinella, A.M., Sanguinetti, G. (2005). Removal of iron and manganese using biological roughing up flow filtration technology, Water Research 39:4463-4475

46. Peleato, N. M., Legge, R. L., \& Andrews, R. C. (2018). Neural networks for dimensionality reduction of fluorescence spectra and prediction of drinking water disinfection by-products. Water research, 136, 84-94.

47. Qu, X.L., Brame, J., Li, Q., Alvarez, J.J.P., (2013). Nanotechnology for a safe and sustainable water supply: enabling integrated water treatment and reuse. Accounts of Chemical Research 46 (3), 834-843.

48. Ravikumar, P., \& Somashekar, R. K. (2017). Principal component analysis and hydrochemical facies characterization to evaluate groundwater quality in Varahi river basin, Karnataka state, India. Applied Water Science, 7(2), 745-755.

49. Sutherland, D. L., Heubeck, S., Park, J., Turnbull, M. H., \& Craggs, R. J. (2018). Seasonal performance of a full-scale wastewater treatment enhanced pond system. Water research, 136, 150-159.

50. Southwest Water Authority (2004). "Water: Water Quality". http://wouthwestwater.com.au/water/ quality.php

51. United States Environmental Protection Authority (2013). Effects of Acid Rain - Materials. Available from World Health Organization (2004a). International Standards for Drinking Water, World Health Organization, Geneva, Switzerland

52. World Health Organization (2004b). Health risks from drinking demineralized water, WHO. USA

53. Zhang, Z., Gao, P., Cheng, J., Liu, G., Zhang, X., \& Feng, Y. (2018). Enhancing anaerobic digestion and methane production of tetracycline wastewater in EGSB reactor with GAC/NZVI mediator. Water research, 136, 54-63. 